\title{
Cytological Changes in the Prolactin Cells of Medaka, Oryzias latipes, along with the Change of Environmental Salinity
}

\author{
Yoshitaka NaGaHama and Kiichiro Yamamoto* \\ (Received February 15, 1971)
}

\begin{abstract}
The detailed morphological changes of the prolactin cells in the pituitary gland of medada (Oryzias latipes) during a short period after transferring the fish from sea water to fresh-water were investigated by means of light and electron microscopes.

The prolactin cells of the fresh-water medaka are stained strongly with azocarmine G and contain secretory granules measuring $200-300 \mathrm{~m} \mu$ in diameter. On the contrary, the cells of the sea water fish are small in size and weak in staining affinity for azocarmine $G$. The secretory granules are small in size and number, and are variable in shape. On the other hand, one to three hours after transferring the sea water fish to fresh-water, their cytoplasm is seen to become occupied with newly synthesized small granules. During these stages, the formation of granules in the Golgi apparatus and the extrusion of granules through the cell membrane were frequently observed. Along with the lapse of time after the transfer, the cells showed increase in size and acquire a staining affinity for azocarmine $G$. Thus, the experimental evidence obtained in the present study seems to support the view that prolactin cells secrete one kind of hormone which plays an important role for the adaptation of the fish to fresh-water.
\end{abstract}

It is accepted generally that the prolactin which is secreted from the pituitary gland is responsible for the adaptation of fishes from sea water to fresh-water environment ${ }^{1}$. Moreover, it has been demonstrated by the light microscopical observations ${ }^{2-5}$, and by the electron microscopical observations ${ }^{6-11)}$, that this hormone is secreted from the eta cells, the so-called prolactin cells, in the pro-adenohypophysis. So far as the authors know, however, there are no detailed investigations made on the responses of the cells during a short term after transferring the fish from sea water to fresh-water.

As it is well known, the medaka, Oryzias latipes, can tolerate a wide range of salinity, when transferred from fresh-water to sea water. According to SHIGAKi et al. ${ }^{13}$, prolactin is also related to the osmoregulation of this species. However, no study has been made on the fine structure of the prolactin cells of the medaka at the time of adaptation to the environment.

So, the authors investigated by means of light and electron microscopes the detailed morphological changes of the prolactin cells in the pituitary gland of the medaka during a short period after transferring the fish from sea water to fresh-water.

\footnotetext{
* Laboratory of Fresh-Water Fish-Culture, Faculty of Fisheries, Hokkaido University, Hakodate,

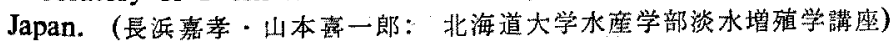




\section{Material and Methods}

The fish used in the present study, the wild type fish of Oryzias latipes, were collected from a pond at Yunokawa Hot Spring, Hakodate, Hokkaido. They were cultured in an outdoor pond located in the campus of Hokkaido University for further research. Experiments were carried out from March to July, 1970. During the experiments the fish were kept at approximately $23^{\circ} \mathrm{C}$ under natural photoperiod conditions. Natural sea water used in the present study was obtained from Hakodate Bay, Hakodate, Hokkaido. The sea water fish, which had been kept in sea water for more than 3 weeks, were transferred directly to fresh-water, for a period of 1,3 , and 10 hours, or 1, 3, 5, 10, and 20 days. Then, the fish were killed and their pituitary glands quickly removed.

For the light microscopical observations, the pituitary glands were fixed for about 24 hours with Heidenhain's susa solutions. Then, serial sagittal sections were made at 5-6 micra from paraffin or 'Tissuemat' embedded blocks and stained by Heidenhain's azan and Halmi's aldehyde fuchsin-light green orange $\mathbf{G}$.

For the electron microscopical observations, the organs were removed and mostly fixed in Millonig's solutions for 2 hours. Some of them were also placed in $2 \%$ glutaraldehyde in $0.05 \mathrm{M}$ phosphate buffer for 1 hour and then immersed in Millonig's solutions for 2 hours. After dehydration in graded ethanols, the organs were embedded in an Epon Epoxy resin mixture. The sections were cut with glass knives in a Porter-Blum microtome at a thickness of about 500 to $800 \AA$, and stained with uranyl acetate and Reynolds' lead citrate, and examined with a Hitachi HS-7 electron microscope. Thick sections of about 1 micron for light microscopy were cut by the same method as above and stained with the method of RICHARDSON et al. ${ }^{13)}$.

\section{Results}

(1) Fresh-water fish The pituitary gland of the medaka can be divided into four regions: pro-adenohypophysis, meso-adenohypophysis, meta-adenohypophysis and neurohypophysis (Fig. 1). The identification of the cell types of each lobe parallels with the investigations reported by Kasuga and Takahashi ${ }^{14}$. The pro-adenohypophysis is composed of two cell types: the prolactin cells and the supporting cells. The prolactin cells occupy the most part of the pro-adenohypophysis and are stained strongly with azocarmine G (Fig. 2). They contain numerous, very fine granules which are stained strongly blue-purple in the Epon-embedded $1 \mu$ sections treated by Richardson's method. The cells are elongate or sometimes polygonal in shape and are $7-10 \mu$ in diameter. The nuclei situated in the central portion of the cells are about $5 \mu$ in diameter and are usually elongate in shape. In electron micrographs, the cells include numerous membrane-bound secretory granules, measuring $200-300 \mathrm{~m} \mu$ in diameter, which are relatively 
uniform in electron density and are round in shape (Fig. 4). The nuclei have a smooth contour. The rough-surfaced endoplasmic reticulum distributing around the nucleus is well developed. Abundant Golgi apparatus composed of a few flattened sacs, many vesicles and several vacuoles are also observed lying close to the nucleus. Mitochondria, moderate in number and short or long rod-shaped, are found distributing sparsely in the cytoplasm, and contain a few intramitochondrial granules. Sometimes, very large and round mitochondria, having many intramitochondrial granules, are also observed (Fig. 6). On the other hand, the supporting cells are located directly adjacent to the blood capillaries and they are full of many well developed mitochondria, but the Golgi apparatus and the endoplasmic reticulum are rather poorly developed in their cytoplasm (Fig. 5).

(2) Sea water fish The pro-adenohypophysis of sea water fish is significantly small due to the decreasing in size of the individual cells when compared with the specimens from fresh-water fish. The cytoplasm of the prolactin cells is little stained with azocarmine G. In the Epon-embedded $1 \mu$ preparations stained with Richardson's method, a few blue purple granules of a very fine size are recognized forming a narrow rim around the nucleus (Fig. 3). However, the nuclei do not differ much in size from those of the fresh-water fish. In electron micrographs, the secretory granules in the cytoplasm are reduced in number, become significantly small in size and are more various in electron density (Fig. 7). The endoplasmic reticulum and Golgi apparatus are poorly developed, but the mitochondria seem to be similar in number and size to those of fresh-water fish.

(3) After transferring the fish from sea water to fresh-water One to three hours after transferring the fish from sea water to fresh-water, it is difficult to find light microscopically a clear difference between the prolactin cells of fresh-water fish and those of sea water fish: the pro-adenohypophysis is small in volume, and its component cells are small in size and are little stained with azocarmine $\mathrm{G}$. However, the nuclei are prominent. In contrast with these results obtained by light microscopical observations, the ultrastructure of the cells showed significant changes in this stage. The prolactin cells are filled with numerous immature granules, of which many are low in electron density and a few show a highly electron dense nature (Fig. 8). Extrusion of the secretory granules into the narrow intercellular space through the cell membrane is frequently observed. Furthermore, the Golgi apparatus become extensive in volume and a new formation of secretory granules in this field is recognized. The rough-surfaced endoplasmic reticulum is also found in a rather extensive area.

One to three days after the treatment, the pro-adenohypophysis increases slightly in volume as compared with that of the previous stage. The individual prolactin cells become also large in size due to the expansion of their cytoplasm. However, the cells are still keeping a weak affinity to azocarmine G. The nuclei are prominent. Mitotic figures are not recognizable. In electron micrographs, the secretory granules near the 
Golgi apparatus are small in size and low in electron density. In addition to these immature granules, however, a few highly electron-dense mature granules appear in the periphery of the cytoplasm. The Golgi apparatus are still very well developed (Fig. 9), and the secretory granules at the beginning of the formation can be observed in the Golgi apparatus. The rough-surfaced endoplasmic reticulum is distributing close to the nucleus in the form of parallel lamellae.

Five days after the treatment, the specimens show that the pro-adenohypophysis is considerably enlarged in volume, though still slightly smaller than that of fresh-water fish. The prolactin cells are increased in size and begin to be stained strongly with azocarmine G. These results obtained by light microscopical observations coincide well with those of electron microscopical ones: the secretory granules increase in size and number, and also in electron density.

In the specimens sacrificed ten days after, the pro-adenohypophysis seems to be similar in volume as that of fresh-water fish. The lobe becomes to occupy the most part of the anterior aspect of the pituitary gland. The cytoplasm of the prolactin cells increase in volume and show a strong affinity for azocarmine G. In electron micrographs, the cells include a considerable number of mature secretory granules throughout the cytoplasm (Fig. 10). The Golgi apparatus and rough-surfaced endoplasmic reticulum are developed well and about the same as those of the fresh-water fish.

\section{Discussion}

The light microscopical characteristics of the prolactin cells in the pituitary of the medaka have been described already by AOKI and UEMURA ${ }^{15)}$ and KASUGA and TAKAHA$\mathrm{SHI}^{14)}$. From their studies it was clarified that the prolactin cells of the medaka are very similar to the eta cells (prolactin cells) of Poecilia pituitary gland ${ }^{3)}$. However, no study on the ultrastructure of the prolactin cells of the medaka had been reported with the exception of a brief account by KASUGA and TAKAHASHI ${ }^{14}$.

The present study confirmed that the secretory granules of the prolactin cells are formed in the Golgi apparatus as in the prolactin cells of the eel pituitary ${ }^{16)}$. Moreover, mature secretory granules are abundant in the prolactin cells of the fresh-water fish. This indicates that the secretory product may perhaps be released at a low level in freshwater fish. Just after the specimens were transferred from sea water to fresh-water, however, the extrusions of granules through the cell membrane were often observed as the same manner as in the prolactin cells of the mouse during late pregnancy ${ }^{17}$.

The prolactin cells of the sea water medaka are smaller in size and weaker in staining affinity for azocarmine $\mathrm{G}$ than those of the fresh-water fish. These results agree with the findings in Poecilia latipinna $a^{2-4)}$ and Tilapia mossambica ${ }^{8)}$. KNOWLES and VollraTH ${ }^{6}$, 
who studied Danish eel with the electron microscope, showed that most of the "prolactin" granules in the specimen caught in sea water measured 2,000 $\AA$ in diameter, whereas. in the river eels they measured about $2,800 \AA$. The same authors ${ }^{18)}$ stated the opinion that the size of vesicles in the cells of the pars distalis may be related to the chemical composition of their contents. From these results, they arrived at the conclusion that the large vesicles in the fresh-water fish may be responsible for the life of the eel in freshwater, whereas the small ones in the sea water fish may be related to the survival of fish in sea water.

On the contrary, BALL and Olivereau ${ }^{2)}$ reported that in Poecilia latipinna, the cytological changes of the prolactin cells were noticeable by 24 hours after transferring the fish to fresh-water. Furthermore, the increased secretory activity of the prolactin cells has been exhibited in Atlantic salmon ${ }^{19}$ and sockeye salmon ${ }^{20}$ just after they ran into a river. On the other hand, it may be certain that the secretion of prolactin from the pituitary gland promotes survival in fresh-water by limiting the outflux of sodium from the body (see BALL and BAKER ${ }^{11}$ ). Moreover, recently, SHIGAKI et al ${ }^{12)}$ indicated that 12 hours after transferring the sea water medaka to fresh-water the plasma sodium dropped by about $30 \%$, while that of the hypophysectomized fish dropped by about $60 \%$.

As stated above, the ultrastructure of the prolactin cells in the sea water medaka showed an inactive appearance; small number and size in the secretory granules, variable shapes in the granules, much reduced rough-surfaced endoplasmic reticulum and the Golgi apparatus. Judging from these findings, it may be reasonable to assume that the small granules of the prolactin cells of sea water medaka are not responsible for the survival of fish in sea water. While, one to three hours after transferring the fish to fresh-water, dramatic signs of functional activation have been demonstrated by the electron microscopical observations. The prolactin cells at this stage were characterized by numerous. smaller secretory granules, in general being low in electron density, though their cytoplasm retained weak affinity to azocarmine G. The well developed Golgi apparatus and rough-surfaced endoplasmic reticulum are also recognized. These marked changes of the prolactin cells in the medaka just after transferring them from sea water to fresh-water may perhaps be related to the secretion of the prolactin, which is supposed to inhibit the sudden outflux of sodium from the body. Therefore, the results obtained in this study seem to give a favorable evidence supporting that the prolactin cells secrete one kind of hormone and that it plays an important role for the adaptation of the fish to the freshwater.

\section{References}

1) J. N. Ball and B. I. Baker: in "Fish physiology" (W. S. Hoar and D. J. Randall, eds.), Vol. II, 1-110, Academic Press, New York \& London (1969). 
2) J. N. Ball and M. Olivereau: C. R. Acad. Sc. Paris, 259, 1443-1446 (1964).

3) M. Olivereau and J. N. Ball: Gen. Comp. Endocrinol, 4, 523-532 (1964).

4) J. N. BALl and G. E. Pickford: Anat. Rec., 148, 358 (1964).

5) E. W. Emmart: Gen. Comp. Endocrinol., 12, 519-525 (1969).

6) F. Knowles and L. Vollrath: Z. Zellforsch., 75, 317-327 (1966).

7) L. Vollrath: Z. Zellforsch., 73, 107-131 (1966).

8) M. Dharmamba and R. S. Nishioka: Gen. Comp. Endocrinol., 10, 409-420 (1968).

9) Y. Nagahama and K. Yamamoto: Bull. Fac. Fish., Hokkaido Univ., 21, 169-177 (1970).

10) M. Abraham and N. Blanc-Livni: Gen. Comp. Endocrinol., 13, 489 (1969).

11) J. F. Leatherland: Z. Zellforsch., 104, 301-317 (1970).

12) T. Shigaki, T. HiRano and S. UChida: Zool. Mag., 78, 394, abstract (In Japanese) (1969).

13) K. C. Richardson, L. Jarett and E. H. FinKe: Stain Technol., 35, 313-323 (1961).

14) S. Kasuga and H. Takahashi: Bull. Fac. Fish., Hokkaido Univ., 21, 79-89 (1970).

15) K. AOKI and H. Uemura: Endocrinol. Japon., 17, 45-55 (1970).

16) C. R. Hopkins and B. I. BAKer: J. Cell Science, 3, 357-364 (1968).

17) M. SANo: J. Cell Biol., 15, 85-97 (1962).

18) F. KNowles and L. Vollrath: Phil. Trans., B. 250, 329-342 (1966).

19) M. Olivereau: Ann. Inst. Oceanog. (Monaco) (N. S.), 29, 95-296 (1954).

20) van Overbeeke and J. R. McBride: J. Fish. Res. Board Canada, 24, 1791-1810 (1967).

\section{Explanation of Plate 1}

Fig. 1. Sagittal section of pituitary gland of fresh-water fish. P, Pro-adenohypophysis; M, meso-adenohypophysis; Mt, meta-adenohypophysis; NH, neurohypophysis. azan. $\times 250$.

Fig. 2. Photomicrograph of $1 \mu$ section of fresh-water fish. Many prolactin cells and a few supporting cells (arrow) are observed. B, blood capillary. $1 \% \mathrm{OsO}_{4} . \quad$ Azur II-methylene blue. $\times 500$.

Fig. 3. Photomicrograph of $1 \%$ section of sea water fish. $1 \%$ OsO $_{4}$. Azur II-methylene blue. $\times 500$.

Fig. 4. Prolactin cells of fresh-water fish. Numerous mature secretory granules are found distributing throughout the cytoplasm. G, Golgi apparatus; M, mitochondrion; ER, endoplasmic reticulum. $1 \% \mathrm{OsO}_{4} . \times 13,800$.

Fig. 5. Supporting cells of fresh-water fish which are located adjacent to blood capillaries (B). Many mitochondria (M) are seen in the cytoplasm. P, prolactin cells; BM, basement membrane; $\mathrm{E}$, endothelial cell. $1 \% \mathrm{OsO}_{4} . \quad \times 10,800$.

Fig. 6. A large mitochondion (M) observed in fish at ten days after the transfer. $1 \% \mathrm{OsO}_{4}$. $\times 22,500$.

\section{Explanation of Plate 2}

Fig. 7. Portion of a prolactin cell of sea water fish. Granules are small in size and various in electron density. The endoplasmic reticulum (ER) and the Golgi apparatus $(G)$ are much reduced. $\mathrm{M}$, mitochondrion. $1 \% \mathrm{OsO}_{4} . \times 23,000$.

Fig. 8. Portion of a prolactin cell of fish three hours after being transferred from sea water to fresh-water. The Golgi apparatus (G) and endoplasmic reticulum (ER) are well developed. Granules are small in size and generally low in electron density. $\quad \mathrm{M}$, mitochondrion. $1 \%$ $\mathrm{OsO}_{4} . \quad \times 23,000$.

Fig. 9. Portion of a prolactin cell of fish three days after being transferred from sea water to fresh-water. A number of mature granules are found distributing in the peripheral cytoplasm. M, mitochondrion; $G$, Golgi apparatus; ER, endoplasmic reticulum. $1 \% \mathrm{OsO}_{4} . \times 23,000$.

Fig. 10. Portion of a prolactin cell of fish ten days after being transferred from sea water to fresh-water. The cytoplasmic organelles are no different from those in the normal freshwater fish. G, Golgi apparatus; ER, endoplasmic reticulum; M, mitochondrion. $1 \%$ $\mathrm{OsO}_{4} . \quad \times 23,000$. 
Plate 1
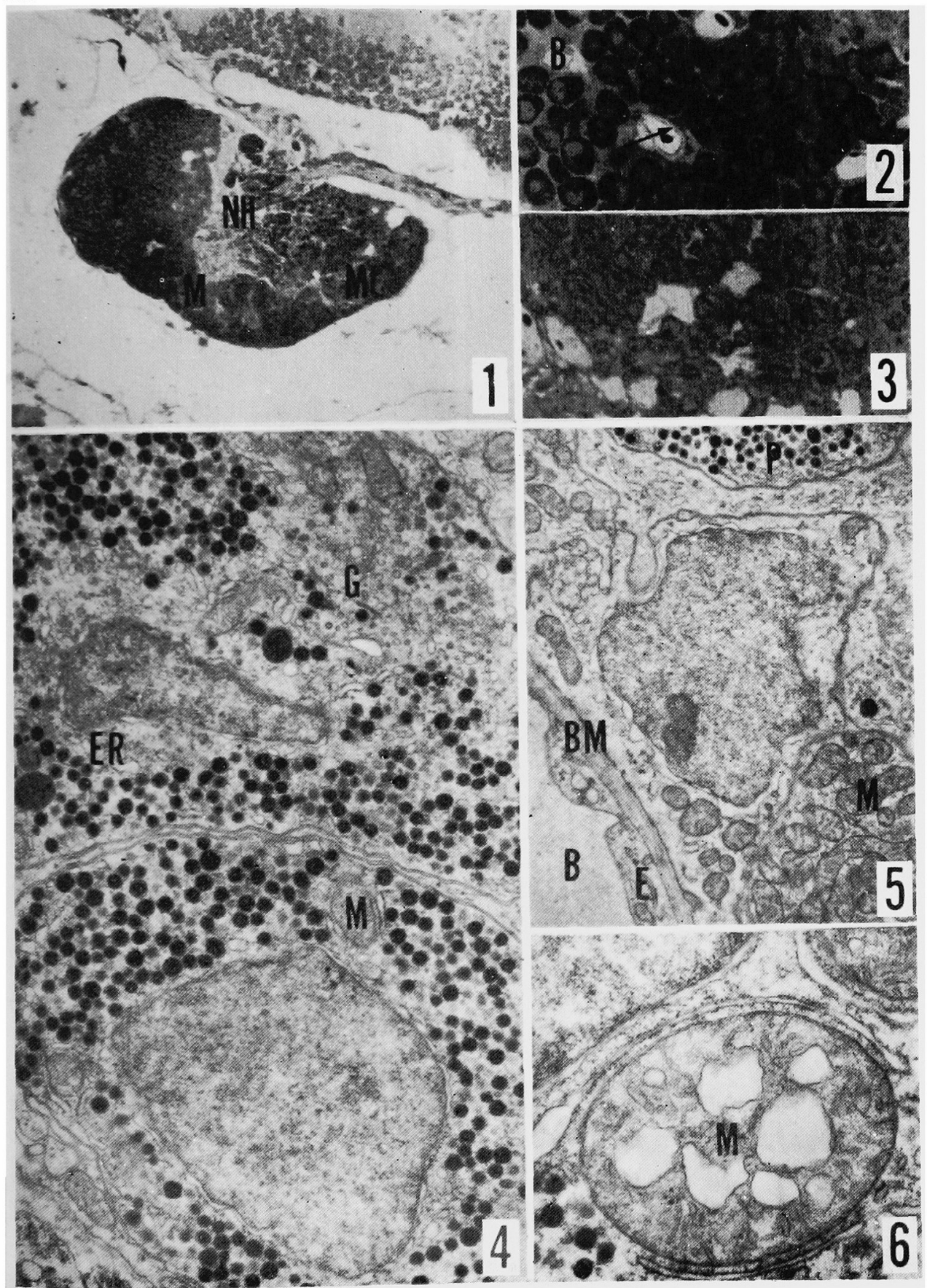
Plate 2
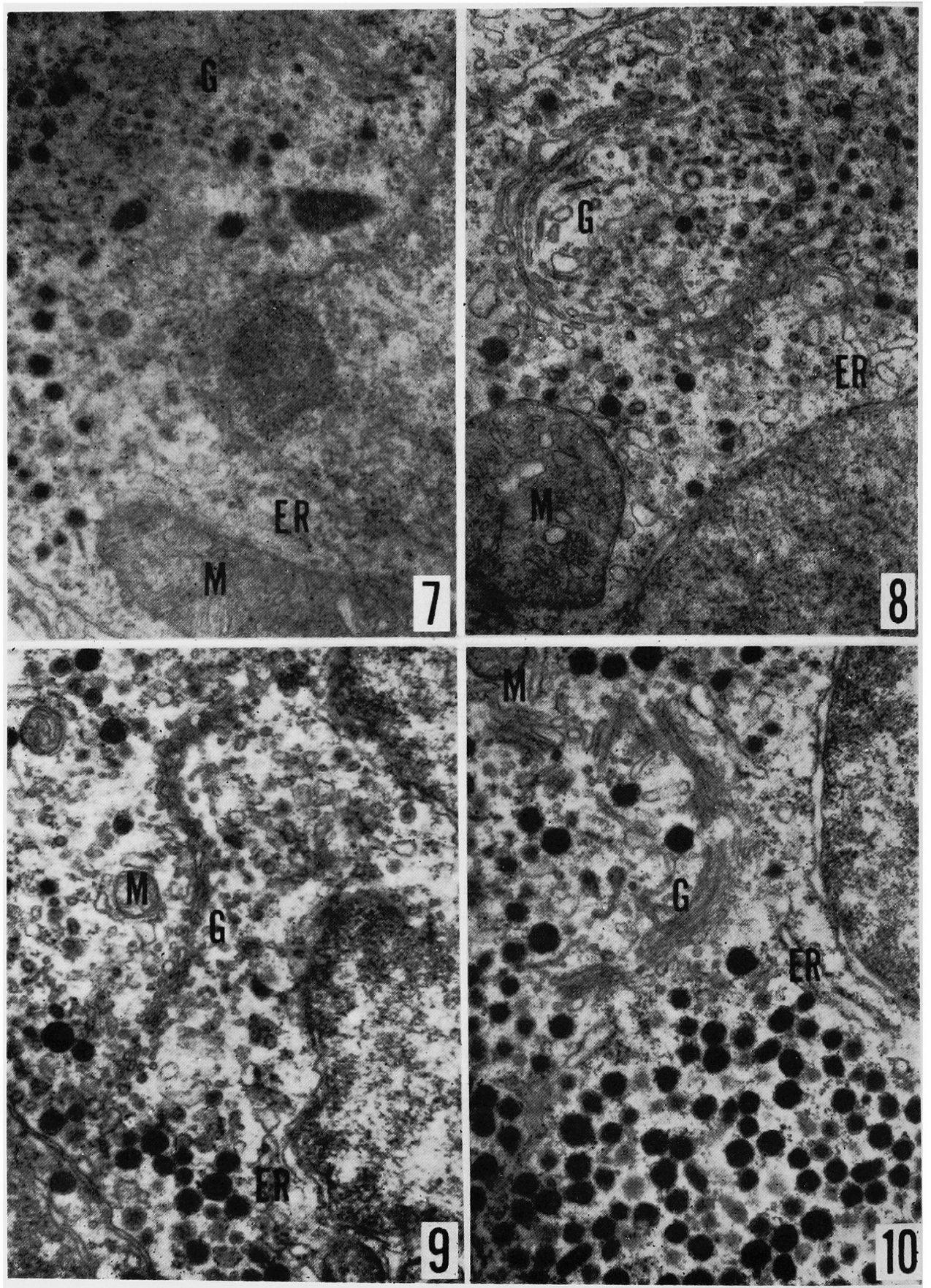